\title{
Genetic polymorphism of the fourth component of complement and Type 1 (insulin-dependent) diabetes
}

\author{
A. Marcelli-Barge ${ }^{1}$, J.C. Poirier ${ }^{1}$, M.Schmid ${ }^{1}$, I. Deschamps ${ }^{2}$, H. Lestradet ${ }^{2}$, P. Prevost ${ }^{1}$, and J. Hors ${ }^{1}$ \\ ${ }^{1}$ Inserm U 93, Hôpital Saint Louis, and ${ }^{2}$ Inserm U 83, Hôpital Hérold, Paris, France
}

\begin{abstract}
Summary. The complement proteins, Bf, C2, C4A and C4B, are closely linked to HLA. In 74 propositi and their families, and 97 controls genotyped for HLA-A, -B, -C, -DR, -Bf, a high incidence of the $\mathrm{C} 4 \mathrm{BQ} 0$ variant was detected in the patient group ( $33 \%$ versus $12 \%, p<0.00001$ ); C4BQ0 was more frequent in propositi than in non-affected siblings (40 out of 74 versus 36 out of $92, p<0.05$ ). When comparing the distribution of the phenotype C4BQ0 in Type 1 diabetic patients and normal control subjects, the difference was significant in pat-
\end{abstract}

ients bearing DR3 or DR4 (56\% and 25\%, respectively, $p<$ 0.003 ). The main linkage disequilibria were observed among the 74 propositi: $\mathrm{B} 18, \mathrm{BfF} 1, \mathrm{C} 4, \mathrm{~A} 3, \mathrm{BQ} 0, \mathrm{DR} 3$; $\mathrm{B} 12, \mathrm{BfS}, \mathrm{C} 4$, A3, BQ0, DR4. The existence of a silent allele at the C4 B locus is known to be associated with a defective immune response.

Key words: HLA, complement, Type 1 diabetes.
The models of inheritance of Type 1 (insulin-dependent) diabetes are all based on the association between disease and markers of the HLA complex; among these the DR3 and DR4 alleles have been universally recognised as playing the predominant rôle [1-3]. The importance of the complement factors $\mathrm{Bf}$ and $\mathrm{C} 4$ has also been pointed out [4-5].

The purpose of this study was to analyse the association between Type 1 diabetes and the silent allele at the C4B locus: C4BQ0. The C4 complement proteins are coded by two strongly linked loci, $\mathrm{C} 4 \mathrm{~A}$ and $\mathrm{C} 4 \mathrm{~B}$, located within the HLA region on the sixth chromosome. To date, 13 alleles have been recognised at the $\mathrm{C} 4 \mathrm{~A}$ locus and 19 at the C4B locus. A silent allele named Q0 has been described at each locus. It is characterised by the absence of precipitation bands when the serum proteins are tested by high voltage immuno-electrophoresis and immunofixation using anti-C4 serum.

\section{Subjects and methods}

\section{Subjects}

We investigated 74 Caucasoid families who had been ascertained through Type 1 diabetic propositi (onset of diabetes occurred before the age of 30 years) at the diabetic clinic of the Herold Hospital, Paris. One child was affected in 53 families, two or more children were affected in 14 families and one parent and one child in seven families. These families included all of the 74 propositi, in all having 88 diabetic subjects. Ninety-seven healthy unrelated subjects served as controls.

HLA typing (HLA-A, B, C, DR and Bf) was performed following techniques described previously $[6,7]$.

C4 typing was carried out in neuraminidase-treated EDTA plasma samples using high voltage immuno-electrophoresis in agarose gel and immunofixation by a xenogenic human anti-C4 serum from the technique described by Awdeh and Alper [8]. The haemolytic $\mathrm{C} 4$ activity was measured using the method of Gaither et al. [9]. The dosage of $\mathrm{C} 4$ fraction was performed with a Beckman nephelometer (Beckman, Fullerton, California, USA). The nomenclature for variants of the two C4 loci was that proposed by Mauff et al. [10].

The haplotypes were clearly established and gene frequencies observed by direct counting. The results for the 74 propositi were compared with the haplotype and gene frequencies in healthy unrelated control subjects. Statistical analysis was carried out using $2 \times 2$ comparisons on $\chi^{2}$ test with Yates' correction.

\section{Results}

The gene frequencies were compared in 74 propositi and 97 control subjects: $\mathrm{C} 4 \mathrm{BQ} 0$ was more frequent in Type 1 diabetic patients than in control subjects $(33 \%$ versus $12 \%, p<0.00001)$. The frequency of the phenotype BQ0 was significantly increased in propositi compared with non-affected siblings ( 40 out of 74 versus 36 out of $92, p<0.05$; Table 1 ). For other affected siblings, the proportion of $\mathrm{C} 4 \mathrm{BQ} 0$ was also increased ( 10 out of $14, p<0.05$ ).

The genotype combinations of the two silent alleles, C4AQ0 and C4BQ0, were studied. The frequencies of the seven possible genotypes were compared in patients with Type 1 diabetes and control subjects. A significant excess of the C4BQ0 allele was observed in the patient group in only a single dose of genes ( $40 \%$ versus $17 \%$, $p<0.001$ ), with no interaction of the C4AQ0 allele. There was no significant excess of either the C4BQ0 genotype or a cis or trans $\mathrm{C} 4 \mathrm{AQ} 0 / \mathrm{BQ} 0$ combination of alleles in comparison with normal subjects. The frequency of $\mathrm{C} 4 \mathrm{AQ} 0 / \mathrm{BQ} 0$ negative individuals appeared to be subsequently lower in patients than in healthy individuals ( $36 \%$ versus $61 \%, p<0.001$ ).

The frequency of C4BQ0, according to DR3 or DR4 allelic combinations, was compared in Type 1 diabetic and control subjects. Figure 1 clearly demonstrates that 
Table 1. Segregation of $\mathrm{C} 4 \mathrm{BQ} 0$ in 74 families including 88 diabetic and 92 non-diabetic siblings

\begin{tabular}{|c|c|c|c|c|c|c|}
\hline \multirow{2}{*}{$\begin{array}{l}\text { Propositi } \\
\text { Shared haplotypes }\end{array}$} & \multicolumn{3}{|c|}{$\begin{array}{l}\text { BQ 0-positive } \\
\text { patients }{ }^{\mathrm{a}} \\
(n=40)\end{array}$} & \multicolumn{3}{|c|}{$\begin{array}{l}\text { BQ 0-negative } \\
\text { patients } \\
(n=34)\end{array}$} \\
\hline & 2 & 1 & 0 & 2 & 1 & 0 \\
\hline $\begin{array}{l}\text { Number of other affected } \\
\text { siblings }^{\text {a }}\end{array}$ & 6 & 4 & 0 & 3 & 1 & 0 \\
\hline $\begin{array}{l}\text { Number of non-affected } \\
\text { siblings }\end{array}$ & 13 & 17 & 6 & 10 & 24 & 22 \\
\hline
\end{tabular}

a $p<0.03$

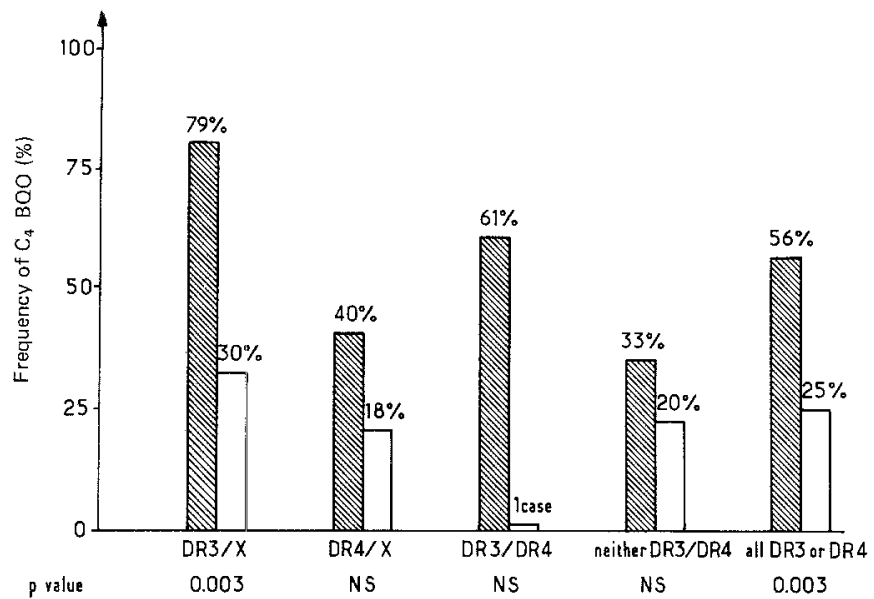

Fig.1. Distribution of C4 BQ 0 in Type 1 diabetic patients and control subjects $\square$

the increased incidence of $\mathrm{C} 4 \mathrm{BQ} 0$ concerns haplotypes bearing either DR3 or DR4 (56\% and 25\%, respectively, $p<0.003$ ). Conversely, no significant increase of C4BQ0 was noted for haplotypes which did not bear either DR3 or DR4. Linkage disequilibrium studies $(2 \times 2)$ allowed us to build haplotypes, including five loci. These haplotypes marked the short parts in linkage disequilibrium. For $\mathrm{B} 18, \mathrm{BfF} 1, \mathrm{C} 4, \mathrm{~A} 3, \mathrm{BQ} 0$, a significant increase in frequency was observed in Type 1 diabetes $(20 \%$ versus $5 \%$ in controls). The apparently increased frequencies of two other haplotypes, B12 BfS, C4, A3, B1, DR4 $(8 \%$ versus $2 \%)$ and $\mathrm{B} 12, \mathrm{BfS}, \mathrm{C} 4, \mathrm{~A} 3, \mathrm{BQ} 0, \mathrm{DR} 4(7 \%$ versus $2 \%$ ) were not significant.

In addition, those who carried the C4BQ0 haplotype had a partial deficiency of $\mathrm{C} 4$ synthesis (mean \pm $\mathrm{SD}, 17.7 \pm 4.7 \mathrm{mg}, \mathrm{n}=18$, versus $20.9 \pm 12.3 \mathrm{mg}, n=8$, in control subjects, $p<0.01$ ) and the mean level of $\mathrm{C} 4$ remained lower in Type 1 diabetic patients than in control subjects $(44 \pm 33 \%, \mathrm{n}=7$, versus $89 \pm 32 \%, n=7$, $p<0.001)$.

\section{Discussion}

This study showed an excess of C4BQ0 in Type 1 diabetic patients, particularly in those who carried DR3 but also in some cases of DR4. Cambon de Mouzon et al. [5] were the first to demonstrate the C4BQ0-DR3 association in diabetic subjects (French Basques) whose age at onset was less than 20 years. However the increase of C4AQ0 reported by McCluskey et al. [11] was not observed in our series.

Several authors have pointed out the possible pathogenetic implications of a partial $\mathrm{C} 4$ defect. Our study confirms the results of Kurtz et al. [12], i.e. that C4BQ0-bearing patients have a decreased C4 synthesis and haemolytic activity compared with normal subjects. Our results suggest the rôle of a single dose effect since no excess of BQ0 homozygosity was observed. An epistatic gene interaction with an HLA class II susceptibility gene could account for these results. Another hypothesis could be that the effective $\mathrm{C} 4$ complement component itself plays a rôle. The role of $\mathrm{C} 4$ in the immune defence against viral infection is well known. The observed excess of $\mathrm{C} 4 \mathrm{BQ} 0$ responsible for a partial defect of $\mathrm{C} 4$ synthesis could link the controversial rôle of viruses in Type 1 diabetes and the genetic background of an impaired immune defence.

\section{References}

1. Schernthaner G, Ludwig H, Max RWR (1977) B-lymphocyte alloantigens and insulin-dependent diabetes mellitus. Lancet 2: 1128

2. De Moerloose P, Jeannet M, Bally C, Raffoux C, Pointel JP, Sizonenko P (1978) HLA and DRw antigens in insulin-dependent diabetes. Br Med J 1: 823-824

3. Rodey GE, White N, Frazer TE, Duquesnoy RJ, Santiago JV (1979) HLA-DR specificities among black Americans with juvenile onset diabetes. $\mathrm{N}$ Engl J Med 301: 810-812

4. Deschamps I, Lestradet H, Marcelli-Barge A, Benajam A, Busson M, Hors J, Dausset J (1979) Properdin factor B alleles as markers for insulin-dependent diabetes. Lancet 2: 793

5. Cambon-De Mouzon A, Ohayon E, Hauptmann G, Sevin A, Abbal M, Sommer E, Vergnes H, Ducos J (1982) HLA-A, B, C, DR antigens, Bf, C4 and glyoxalase I (GLO) polymorphism in French Basques with insulin-dependent diabetes mellitus. Tissue Antigens 19: 366-379

6. Deschamps I, Lestradet M, Bonaiti C, Schmid M, Busson M, Benajam A, Marcelli-Barge A, Hors J (1980) HLA-genotype studies in juvenile insulin-dependent diabetes. Diabetologia 19: 189-193

7. Alper CA, Boenijch T, Watson L (1972) Genetic polymorphism in human glycine-rich beta glycoprotein. J Exp Med 135: 68-80

8. Awdeh ZL, Alper CA (1980) Inherited structural polymorphism of the fourth component of human complement. Proc Natl Acad Sci USA 77: $3576-3580$

9. Gaither TA, Alling DW, Franck MM (1974) A new one-step method for the functional assay of the fourth component (C4) of human and guinea pig complement. J Immunol 113: 574-583

10. Mauff G, Alper CA, Awdeh ZL, Batchelor JR, Bertrams J, BruunPetersen G, Dawkins RL, Demant P, Edwards J, Grosse-Wilde H, Hauptmann G, Klouda P, Lamm L, Mollenhauer E, Nerl C, Olaisen B, O'Neill G, Rittner C, Roos MH, Skanes V, Teisberg P, Wells L (1983) Statement on the nomenclature of human C4 allotypes. Immunobiology 164: 184-191

11. McCluskey J, McCann VJ, Kay PH, Zilko PJ, Christiansen FT, O'Neill GJ, Dawkins RL (1983) HLA and complement allotypes in Type 1 (insulin-dependent) diabetes. Diabetologia 24: 162-165

12. Kurtz F, Juif JG, Hauptmann GR, Goetz J (1981) Insulin-dependent diabetes in children and $\mathrm{C} 4$ fraction of complement. Arch F Pediatr 38: 534-535

Dr. A. Marcelli-Barge

INSERM U 93

Hospital Saint Louis

F-75010 Paris

France 